\title{
Hematologic Malignancy-Associated Skin Squamous Cell Carcinoma
}

National Cancer Institute

\section{Source}

National Cancer Institute. Hematologic Malignancy-Associated Skin Squamous Cell

Carcinoma. NCI Thesaurus. Code C160666.

A squamous cell carcinoma that arises from the skin in a patient with a history of hematologic malignancy, usually non-Hodgkin lymphoma or chronic lymphocytic leukemia. 